\title{
Role of prostaglandin $F-2 \alpha$ and oxytocin in the regression of GnRH-induced abnormal corpora lutea in anoestrous ewes*
}

\author{
M. G. Hunter, V. J. Ayad $\dagger$, C. L. Gilbert $\dagger$, J. A. Southee and D. C. Wathes $\dagger$
}

AFRC Research Group on Hormones and Farm Animal Reproduction, University of Nottingham, Sutton Bonington, Leics LE12 5RD, U.K.; and †Department of Anatomy, The Medical School, Bristol BS8 1TD, UK

\begin{abstract}
Summary. Anoestrous Romney Marsh ewes with $(+P)$ and without $(-P)$ progesterone pretreatment were induced to ovulate by multiple low-dose injection of GnRH followed by a bolus injection of GnRH. Luteal function was assessed by twice daily measurement of plasma progesterone. Animals were slaughtered on Days 3 or 5 after the end of GnRH treatment and $\mathrm{CL}$ and endometrium were recovered. In all Day-5 ewes, blood samples were collected at 30 -min intervals for $8 \mathrm{~h}$ on Days 3 and 5 for measurement of PGFM and oxytocin. At slaughter $92 \%$ of the Group $+\mathrm{P}$ ewes had ovulated compared with $54 \%$ of the Group $-\mathrm{P}$ ewes. The ovaries of some of the Group - P ewes only contained luteinized cysts either alone or in association with CL. In the ewes that ovulated, progesterone profiles were normal in all Group $+\mathrm{P}$ ewes, whereas Group - $\mathbf{P}$ ewes had 'normal' or 'abnormal' profiles in which plasma progesterone was declining prematurely. All of the CL from ewes with abnormal progesterone profiles were associated with follicular cysts, and were significantly smaller and with a lower progesterone content on Day 5. PGFM levels decreased $(P<0.05)$ between Days 3 and 5 in ewes in Groups $+P$ and $-P$ with 'normal' CL but increased $(P<0.01)$ in Group $-P$ ewes with 'abnormal' $C L$. Oxytocin levels were lower in Group - $P$ ewes with 'abnormal' $C L$ on Day 5 , than in 'normal' ewes in Groups - $\mathbf{P}$ $(P<0.01)$ or $+\mathrm{P}(P<0.05)$. In $3 / 5$ Day-5 ewes with 'abnormal' $\mathrm{CL}$ there was a clear association between a major peak of oxytocin and a rise in PGFM during the frequent sampling period on Day 3 or Day 5 , and endometrial oxytocin binding sites were present at slaughter. This suggests that the premature regression of 'abnormal' $C L$ occurs via the normal luteolytic mechanism. Although ewes in Groups $+\mathrm{P}$ and $-\mathrm{P}$ with 'normal' $\mathrm{CL}$ had similar progesterone profiles, plasma oxytocin was significantly higher $(P<0.05)$ in the Group $-P$ ewes and oxytocin binding sites were present only in this group, suggesting that progesterone pretreatment can influence the production of both oxytocin and its receptor.
\end{abstract}

Keyw'ords: abnormal corpus luteum; oxytocin; prostaglandin F-2 $\alpha$; ewe; luteolysis

\section{Introduction}

It is now well documented that abnormal luteal function frequently follows ovulation induced in anoestrous ewes by multiple low-dose injections of gonadotrophin-releasing hormone ( $\mathrm{GnRH})$, unless the animal has previously been primed with progesterone (McLeod et al., 1982; Southee et al., 1988a). These short luteal phases were characterized by a transient rise in plasma progesterone 
concentrations to about $0.5 \mathrm{ng} / \mathrm{ml} 3$ days after $\mathrm{GnRH}$ treatment which declined to basal values between Days 4 and 5. Premature regression of these inadequate corpora lutea can be prevented by removal of the uterus (Southee et al., 1988b), suggesting the involvement of a uterine luteolysin.

In the cyclic ewe, luteal function is terminated by the release of prostaglandin (PG) F-2 $\alpha$ from the uterus in pulses which increase in frequency and magnitude as the circulating concentrations of progesterone decline and oestradiol increase (McCracken et al., 1972; Barcikowski et al., 1974; Baird et al., 1976). The initiation of luteolysis is thought to involve oxytocin, which is present in the corpus luteum of the ewe (Wathes \& Swann, 1982) and may engage in a positive feedback loop with PGF-2 $\alpha$ (Flint \& Sheldrick, 1983), providing that sufficient uterine oxytocin receptors are present. Their number is regulated by the concentrations of circulating steroids and starts to rise on about Day 14 of the cycle (Roberts et al., 1976; Sheldrick \& Flint, 1985).

The purpose of the present study was to investigate whether PGF-2 $\alpha$ and/or oxytocin play a major role in the premature regression of these abnormal corpora lutea. This would be suggested by a pulsatile release pattern similar to that found during normal luteolysis. Alternatively, if the concentrations of the two hormones were similar to those found during the normal early luteal phase, this would suggest a possible increase in sensitivity of the abnormal corpus luteum to luteolytic hormones.

\section{Materials and Methods}

Animal treatment and blood sampling. Romney Marsh ewes $(\mathrm{N}=39)$ were used during seasonal anoestrus and were housed under conditions of natural daylength and temperature and fed a diet of concentrates and hay with water always available.

Some ewes were pretreated with progesterone $(+P)$ using intravaginal sponges containing 30 mg fluorogestone acetate (Chronogest: Intervet Laboratories Ltd, Cambridge, UK) which were left in situ for 7 days and removed at the time of the second GnRH injection. Multiple injections of 250 ng synthetic GnRH (Lutal: Fabwerke Hoechst AG, Frankfurt, West Germany) in $2 \mathrm{ml}$ sterile saline $(0.154 \mathrm{M}-\mathrm{NaCl})$ were administered via an indwelling jugular vein catheter every $2 \mathrm{~h}$ for $36 \mathrm{~h}$ (Group + P: 12 ewes) or $18 \mathrm{~h}$ (Group -P: 27 ewes) culminating in a bolus injection of $125 \mu \mathrm{g} \mathrm{GnRH}$ to synchronize the LH surge as described previously (Hunter et al., 1988). The bolus injections were given just before the ewes would have had a spontaneous LH surge, this being earlier in the Group - P ewes than the Group +P ewes (McLeod et al., 1982), and have been shown to have no effect on ovulation rate or luteal function. Blood samples $(3 \mathrm{ml})$ were collected via the jugular vein catheter at $2-\mathrm{h}$ intervals during the treatment and for a further $8 \mathrm{~h}$ after the bolus injection. The plasma was stored at $-20^{\circ} \mathrm{C}$ for subsequent $\mathrm{LH}$ determination.

Twice daily blood samples $(5 \mathrm{ml})$ for progesterone analysis were collected from all animals until slaughter. The time of the administration of the bolus injection of $\mathrm{GnRH}$ was considered to be time 0 , and 6 Group $+\mathrm{P}$ and $7 \mathrm{Group}$ -P ewes were slaughtered after $72 \mathrm{~h}$ (Day 3). The remaining 6 Group $+P$ and 20 Group $-P$ ewes were slaughtered after $120 \mathrm{~h}$ (Day 5). All the Day-5 ewes were subjected to two 8-h periods of blood sampling every 30 min between 72 and $80 \mathrm{~h}$ and 112 and $120 \mathrm{~h}$ after the bolus injection. Blood samples $(15 \mathrm{ml})$ were collected on ice, centrifuged immediately and $5 \mathrm{ml}$ plasma for oxytocin RIA were acidified by the addition of $0.25 \mathrm{ml} 0.1 \mathrm{~N}-\mathrm{HCl}$, snap-frozen on solid $\mathrm{CO}_{2}$ and stored at $-20^{\circ} \mathrm{C}$. This procedure has been shown to prevent loss of oxytocic activity during storage (Homeida \& Cooke, 1984). The remainder of the plasma was frozen and stored at $-20^{\circ} \mathrm{C}$ for measurement of the PGF-2 $\alpha$ metabolite, 15-keto-13,14-dihydro PGF-2a (PGFM).

Treatment of ovarian and uterine tissue. Immediately after slaughter the reproductive tract was placed on ice and the endometrium $\left(2 \mathrm{~g}\right.$ ) was removed by dissection within $20 \mathrm{~min}$ of death and placed in liquid $\mathrm{N}_{2}$ for later measurement of oxytocin binding sites. We have shown that these are maintained during storage.

The follicular fluid was aspirated from the 3 largest follicles per ovary, the volume measured, and added to $1 \mathrm{ml}$ buffer and stored at $-20^{\circ} \mathrm{C}$ for oestradiol RIA. The corpora lutea (CL) and any luteinized cysts were dissected, weighed, their appearance recorded and small pieces $(10-40 \mathrm{mg})$ frozen at $-20^{\circ} \mathrm{C}$ for subsequent determination of progesterone content. The remaining tissue was fixed in $2 \cdot 5 \%$ glutaraldehyde, $4.0 \%$ paraformaldehyde in $0 \cdot 1 \mathrm{M}-$ sodium cacodylate buffer $\mathrm{pH} 7.4$ for 6 days followed by dehydration and embedding in paraplast for subsequent histological analysis. Tissue sections $(7 \mu \mathrm{m})$ were cut and stained with haematoxylin and eosin. These were used to distinguish between cysts and CL using the following criteria in decreasing order of importance: (1) the pattern and alignment of cells created by the infolding of the theca during follicular collapse at ovulation: folds were still present in corpora lutea on Day 5, but were not seen at all in cysts, in which the tissue was more disorganized; (2) the thickness of the tissue wall relative to the lumen: cysts tended to have thin walls and the lumen had a smooth outline, whereas CL had a thicker wall with a corrugated luminal surface; (3) the appearance of the large luteal cells: in cysts these were often elongated and arranged in rows with the long axis perpendicular to the tissue lumen. A similar finding was noted by Cran (1983). 
Hormone radioimmunoassays. Concentrations of $\mathrm{LH}$ in peripheral plasma were assayed using the specific doubleantibody radioimmunoassay of Foster \& Crighton (1974) as modified by McLeod et al. (1982). The limit of sensitivity within this study was $0 \cdot 15 \mathrm{ng}$ NIH-LH-S24 equiv./ml plasma, and the intra-assay coefficient of variation was $<10 \%$.

The oxytocin measurements in plasma were performed as described previously (Wathes et al., 1983, 1986) except that a different antiserum (85/2, raised and characterized by Dr Janis Fletcher in the Department of Anatomy, University of Bristol) was used. This cross-reacts $32 \%$ with mesotocin but not with arginine vasopressin, lysine vasopressin, arginine vasotocin, or neurophysin I or II (all $<0.1 \%$ ). The sensitivity of the assay was $0.4 \mathrm{pg}$ per tube (equivalent to $0.6 \mathrm{pg} / \mathrm{ml}$ plasma) and the inter- and intra-assay coefficients of variation were $12.0 \%$ and $4.9 \%$ respectively.

PGFM concentrations in plasma were measured according to the method of Kaker et al. (1984). Samples of 0.5 ml plasma were acidified with $0.05 \mathrm{ml} 1 \mathrm{~N}-\mathrm{HCl}$ and extracted with $2 \mathrm{ml}$ diethyl ether. The mean extraction efficiency was $81 \pm 2.8 \%$, the limit of sensitivity $40 \mathrm{pg} / \mathrm{ml}$ and inter- and intra-assay coefficients of variation were 15 and $7 \%$ respectively.

The determination of progesterone in peripheral plasma was carried out using the radioimmunoassay method described by Hunter et al. (1986). The assay showed negligible cross-reaction with other major steroids and within this study the limit of sensitivity was $0.1 \mathrm{ng} / \mathrm{ml}$ plasma, the mean extraction efficiency was $83 \pm 3 \%$ and inter- and intra-assay coefficients of variation were both $<12 \%$. Tissue content of progesterone was measured by homogenizing the tissue in a total volume of $5 \mathrm{ml}$ double-distilled ethanol using a polytron homogenizer. Aliquants $(100 \mu \mathrm{l})$ of the ethanol extract were subsequently evaporated to dryness in extraction tubes and redissolved in assay buffer for direct RIA of progesterone as described by Hunter $e t$ al. (1988). Inter- and intra-assay coefficients of variation were again both $<12 \%$.

Oestradiol concentrations in diluted follicular fluid were measured after extraction according to the method of Foxcroft et al. (1984) as validated by Hunter et al. (1986), with a limit of sensitivity of $0.05 \mathrm{ng} / \mathrm{ml}$ and a mean recovery of $92 \pm 0.75 \%$. Inter- and intra-assay coefficients of variation were both $<8 \%$.

All samples for radioimmunoassay were analysed within 9 months of collection.

Measurement of oxytocin binding sites. Samples of endometrium were removed from liquid nitrogen and thereafter all extraction procedures were performed at $4^{\circ} \mathrm{C}$. Samples were homogenized (Ystral homogeniser, Ystral $\mathrm{GmBH}$, Ballrechten-Dottingen, West Germany) in 10 volumes (relative to wet weight) of $10 \mathrm{~mm}$ Tris- $\mathrm{HCl}(\mathrm{pH} 7 \cdot 4)$ containing $0.5 \mathrm{~mm}$-dithiothreitol (DTT) and $1 \mathrm{~mm}$-EDTA. Homogenates were filtered through surgical gauze and centrifuged $(2000 \mathrm{~g}, 10 \mathrm{~min})$. Pellets were discarded and supernatants centrifuged again $(165000 \mathrm{~g}, 40 \mathrm{~min})$. Supernatants were then discarded and pellets washed by resuspension in 5 volumes (relative to original wet weight) of $10 \mathrm{mM}$ Tris- $\mathrm{HCl}$ (pH 7.4) containing 0.5 mM-DTT, $1.0 \mathrm{~mm}$-EDTA and centrifugation $(165000 \mathrm{~g}, 40 \mathrm{~min})$. Supernatants were discarded and pellets resuspended in $50 \mathrm{~mm}$ Tris- $\mathrm{HCl}\left(\mathrm{pH} \mathrm{7.4)}\right.$ and stored at $-80^{\circ} \mathrm{C}$. The protein concentration in the crude membrane preparations was determined by the method of Lowry et al. (1951) using bovine serum albumin as standard.

The relative concentrations of oxytocin binding sites in the membrane fractions were estimated by determining the specific binding of each sample at a saturating concentration of $\left[{ }^{3} \mathrm{H}\right]$ oxytocin, based on the method of Sheldrick \& Flint (1985). Before assay membrane fractions were thawed and washed by centrifugation $(165000 \mathrm{~g}, 40 \mathrm{~min})$, pellets were resuspended in an appropriate volume of Buffer A ( $50 \mathrm{~mm}$ Tris- $\mathrm{HCl}, \mathrm{pH} 7 \cdot 4$, containing $0.1 \%(\mathrm{w} / \mathrm{v})$ bovine serum albumin and $\left.10 \mathrm{~mm}-\mathrm{MnCl}_{2}\right)$. Membrane fractions $(100 \mu \mathrm{g}$ protein) were incubated in Buffer A with $16 \mathrm{~nm}-$ [tyrosyl- ${ }^{3} \mathrm{H}$ ]oxytocin (sp. act. $23 \cdot 7 \mathrm{Ci} / \mathrm{mmol}$ : NEN Research Products, Du Pont (UK) Ltd, Stevenage, UK, stored at $4^{\circ} \mathrm{C}$ and used within 2 months of purchase). This was carried out at $25^{\circ} \mathrm{C}$ for $30 \mathrm{~min}$ (conditions found to be optimal for this tissue). Non-specific binding was determined in the presence of $10^{-6} \mathrm{M}$ unlabelled oxytocin (CRB, Cambridge, UK).

Incubations were terminated by the addition of $3 \mathrm{ml}$ ice-cold Buffer $\mathrm{A}$, followed by rapid filtration under vacuum through Whatman GF/C filters using an Ilacon harvester (Ilacon Ltd, Tonbridge, UK). Filters were washed 3 times with $3 \mathrm{ml}$ ice cold buffer and were then placed in scintillation vials with $3 \mathrm{ml}$ Unisolve E scintillator (Koch-Light Ltd, Haverhill, UK) and counted for $20 \mathrm{~min}$ on a liquid scintillation counter (LKB 1219, LKB Pharmacia, Milton Keynes, UK), which had previously been calibrated to convert c.p.m. to d.p.m. (mean percentage error was $4 \cdot 2 \%$ ).

Total binding and non-specific binding were determined in triplicate (intra-assay coefficient of variation $4.7 \%$ ) for each sample. Binding of $\left[{ }^{3} \mathrm{H}\right]$ oxytocin to the filters in the absence of membranes $\left(<0 \cdot 1 \%\right.$ total $\left[{ }^{3} \mathbf{H}\right]$ oxytocin) was subtracted from all counts. Specific binding was taken as total binding minus non-specific binding $(<0 \cdot 3 \%$ total $\left[{ }^{3} \mathrm{H}\right]$ oxytocin) and was expressed as fmol $\left[{ }^{3} \mathrm{H}\right]$ oxytocin/mg protein. This method gave comparable results in our hands to those recorded by Sheldrick \& Flint (1985). Measurements from cyclic ewes on Days 0-1, 2-3 and 4-6 of the oestrous cycle were $450 \pm 35(n=3), 150 \pm 132(n=2)$ and $52 \pm 29(n=3) \mathrm{fmol} / \mathrm{mg}$ protein respectively.

Statistical analysis. All comparisons between the different groups were carried out by analysis of variance (ANOVA) and subsequent comparisons between individual means by Student's $t$ test.

\section{Results}

\section{Ovarian responses to treatment}

This was judged on the basis of the gross appearance of the ovaries at slaughter, coupled with careful histological analysis of all the luteinized structures which were obtained. The results are 
shown in Table 1. All but one of the Group $+P$ ewes were judged to have ovulated, based on the finding of normal $\mathrm{CL}$ in the ovaries. The ovaries from the Group $-\mathrm{P}$ ewes showed a range of responses. Combining the results for Days 3 and 5 the figures were: no response, $17 \%$ of animals treated; CL only, $29 \%$ CL plus luteinized cysts, $25 \%$, and cysts only, $29 \%$. Overall, only $54 \%$ of the Group - P ewes were judged to have ovulated, compared with $92 \%$ of the Group $+\mathbf{P}$ ewes. There was no difference in the mean ovulation rate between the ewes which had only CL in the ovaries (Group + P, $2 \cdot 0 \pm 0 \cdot 23$; Group $-\mathrm{P}, 1 \cdot 7 \pm 0 \cdot 18$ ). However, the ovulation rate was lower $(1 \cdot 2 \pm 0 \cdot 17, P=0 \cdot 052)$ in those ewes with cysts as well as CL.

Table 1. Ovarian response of ewes to treatment

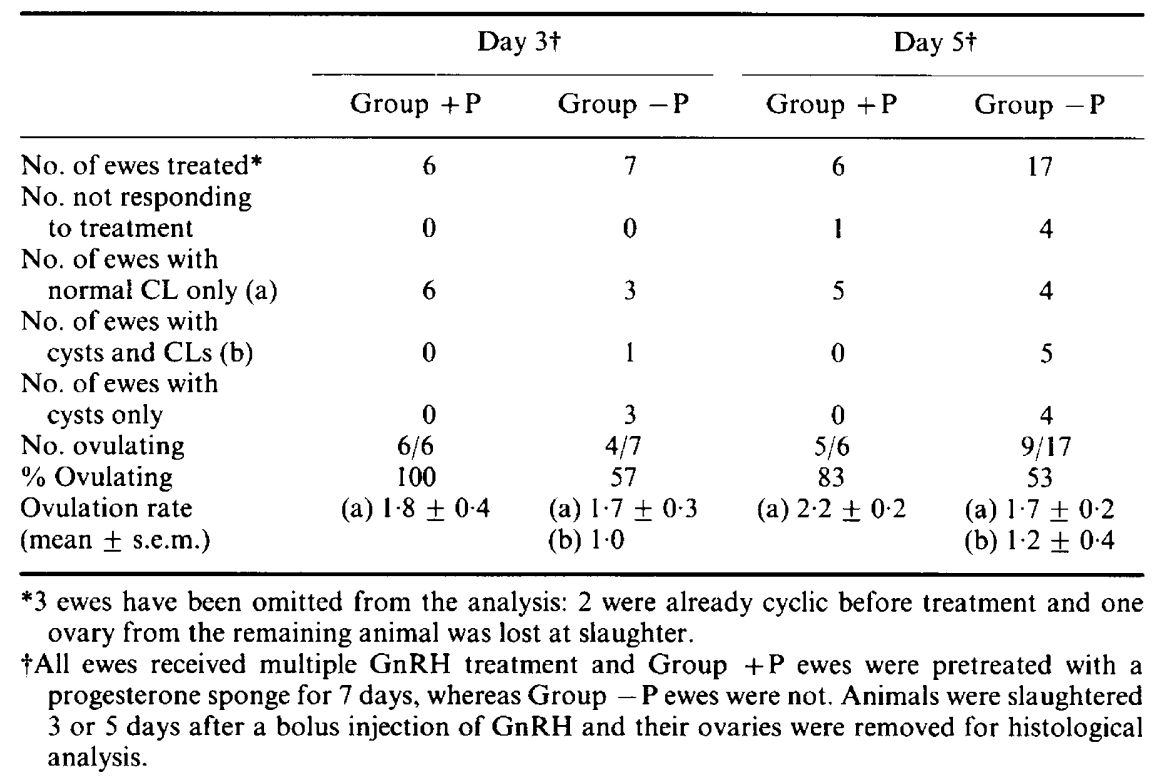

The average weights and progesterone contents of all the CL were measured, and the results are shown in Table 2. On Day 3, the CL in all 3 groups were indistinguishable. On Day 5, there were no differences in the characteristics of the Group $+\mathbf{P}$ and Group $-\mathbf{P}$ ewes in which the ovaries contained CL only. However, in Group $-\mathrm{P}$ ewes with cysts the CL were of significantly $(P<0 \cdot 01)$ lower weight ( 76 compared with $312 \mathrm{mg}$ ) and contained significantly $(P<0.01)$ less progesterone ( 9 compared with $42 \mathrm{ng} / \mathrm{mg}$ ). All of the cysts collected were judged to have luteinized based on both gross and histological appearance and, although the progesterone content of only a few of these was measured, they all contained some progesterone (range $1.4-38.8 \mathrm{ng} / \mathrm{mg}, n=5$ ).

\section{$L H$ responses}

All of the ewes featured in Table 1 showed an ovulatory discharge of LH in response to the bolus injection ranging from 29 to $85 \mathrm{ng} / \mathrm{ml}$. There were no significant differences in the height of the response between the treatment groups or between animals which ovulated and those which did not.

\section{Progesterone profiles}

These are illustrated in Fig. 1. The hormone profiles of the ewes killed on Day 3 and on Day 5 were similar and so both time periods can be considered together. All of the Group $+\mathrm{P}$ ewes that 
Table 2. Corpus luteum characteristics on Days 3 and 5 after ovulation

\begin{tabular}{|c|c|c|c|c|c|c|}
\hline & \multicolumn{3}{|c|}{ Day 3} & \multicolumn{3}{|c|}{ Day 5} \\
\hline & \multirow{2}{*}{$\frac{\text { Group }+P \text { ewes }}{C L \text { only }}$} & \multicolumn{2}{|c|}{ Group - P ewes } & \multirow{2}{*}{$\frac{\text { Group }+\mathrm{P} \text { ewes }}{\mathrm{CL} \text { only }}$} & \multicolumn{2}{|c|}{ Group - P ewes } \\
\hline & & CL only & $\mathrm{CL}+$ cysts & & $\mathrm{CL}$ only & $\mathrm{CL}+$ cysts \\
\hline No. of ewes & 6 & 3 & 1 & 5 & 4 & 5 \\
\hline No. of $\mathrm{CL}$ & 11 & 5 & 1 & 11 & 7 & 6 \\
\hline CL weight (mg)* & $199 \pm 49 \cdot 5$ & $155 \pm 45 \cdot 7$ & 180 & $297 \pm 14 \cdot 5^{a}$ & $330 \pm 30 \cdot 2^{a}$ & $76 \pm 22 \cdot 5^{b}$ \\
\hline $\begin{array}{l}\text { CL progesterone } \\
\text { content } \\
\text { (ng/mg tissue)* }\end{array}$ & $28 \pm 2.7$ & $21 \pm 3 \cdot 3$ & 27 & $43 \pm 4 \cdot 7^{\mathrm{c}}$ & $41 \pm 6.4^{c}$ & $9 \pm 4 \cdot 2^{d}$ \\
\hline
\end{tabular}

Values are mean \pm s.e.m.

a $>$ b, $P<0.01$.

c $>\mathrm{d}, P<0.01$.

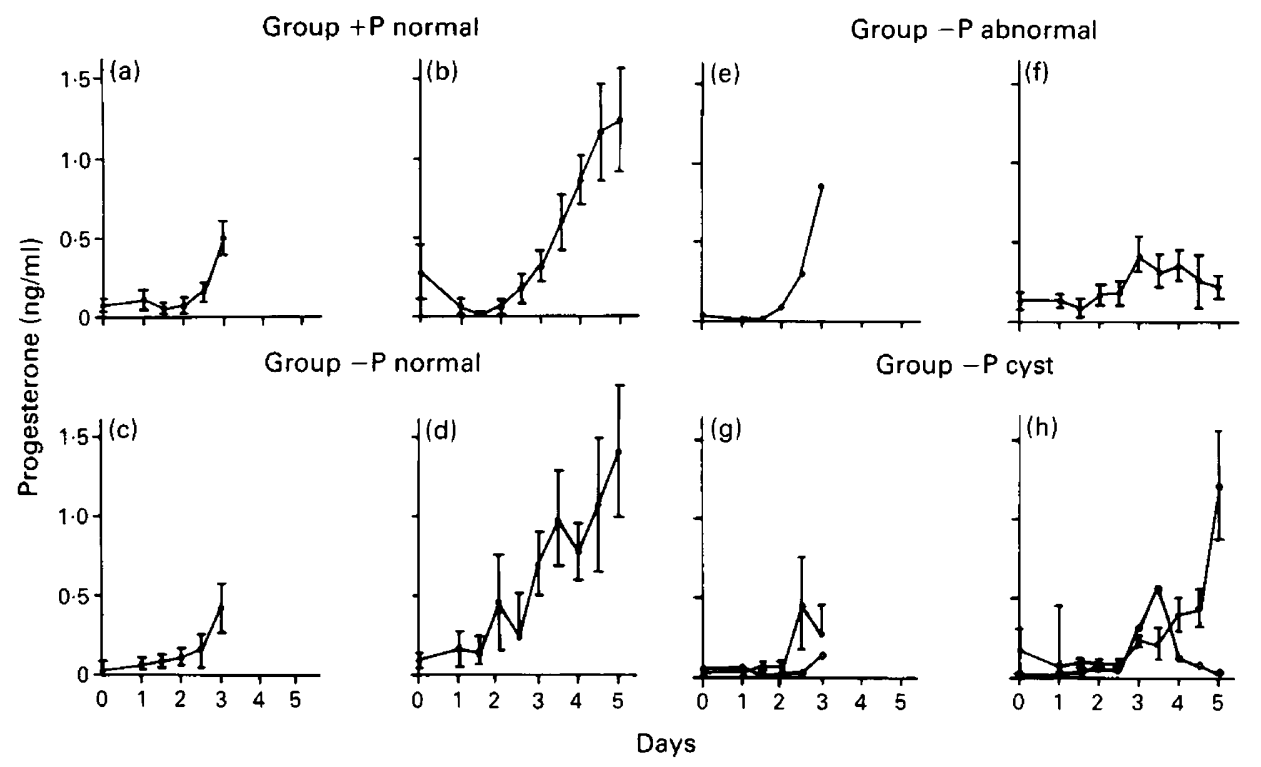

Fig. 1. Progesterone profiles (mean \pm s.e.m.) of anoestrous ewes treated with GnRH (250 ng/ $2 \mathrm{~h}$ ) for $36 \mathrm{~h}$ (Group $+\mathrm{P}$ ewes) or $18 \mathrm{~h}$ (Group $-\mathrm{P}$ ewes) plus a bolus injection of GnRH $(125 \mu \mathrm{g})$. (a, b) Group $+\mathrm{P}$ ewes with normal CL until slaughter on Day $3(\mathrm{~N}=6)$ or Day 5 $(\mathrm{N}=5)$; (c, d) Group $-\mathrm{P}$ ewes with normal $\mathrm{CL}$ until slaughter on Day $3(\mathrm{~N}=3)$ or Day 5 $(\mathrm{N}=4) ;(\mathbf{e}, \mathbf{f})$ Group $-\mathrm{P}$ ewes with abnormal $\mathrm{CL}$ plus cysts until slaughter on Day $3(\mathrm{~N}=1)$ or Day $5(\mathrm{~N}=5) ;(\mathrm{g}, \mathbf{h})$ Group $-\mathrm{P}$ ewes with cysts only until slaughter on Day $3(\boldsymbol{\Theta}, \mathrm{N}=2$; $\mathrm{O}, \mathrm{N}=1)$ or Day $5(\boldsymbol{O}, \mathrm{N}=3 ; \mathrm{O}, \mathrm{N}=1)$.

ovulated showed an increase in progesterone which continued to rise until the end of the sampling period and was typical of ewes exhibiting 'normal' luteal function. The progesterone profiles of the Group $-\mathrm{P}$ ewes divided into two groups, similar to those described by Southee et al. (1988a). In this paper 'abnormal' luteal function was defined as an increase in plasma progesterone concentrations above baseline values followed by a decline to basal levels by $108 \mathrm{~h}$ after the bolus injection 

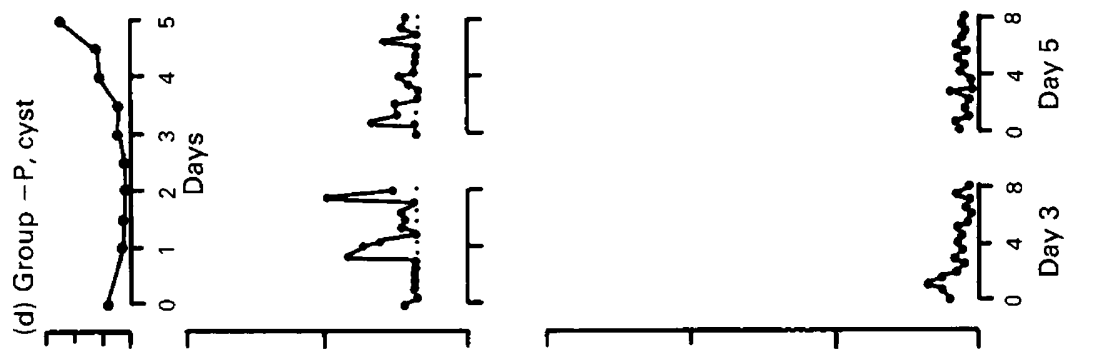

들룔

ㅇํㅇ

즐

층

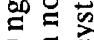

局

讨

作 डิ口 $0+0$
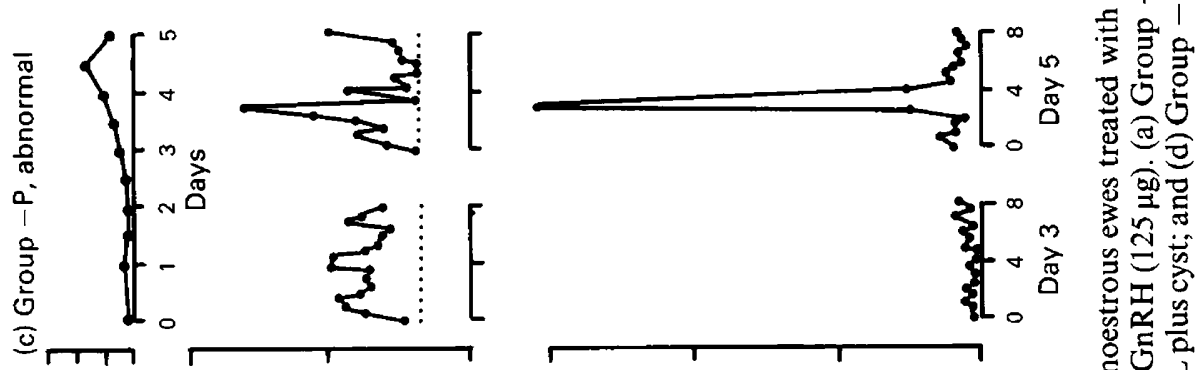

की

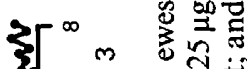

证

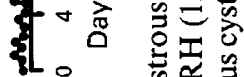

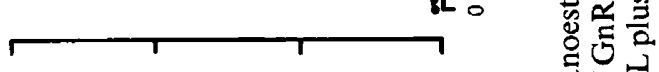

는

可

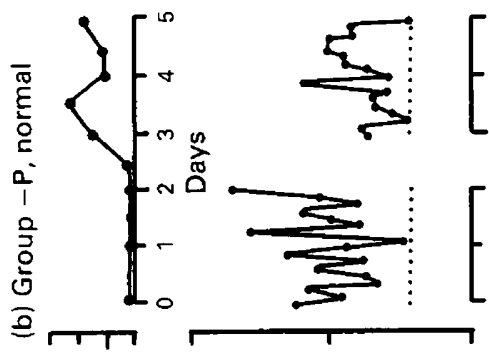

을

. $\Xi 0$

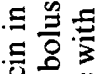

政窎

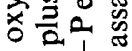

क्ष

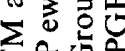

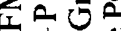

।

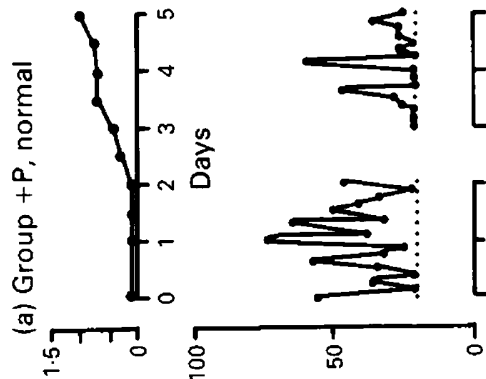

(Iw/6u)

วบ0.1ว15ว601d
( $w / 6 d) ~ W\lrcorner \supset d$

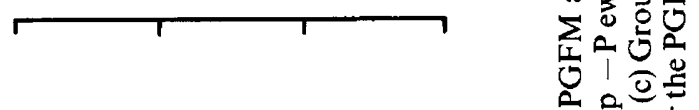

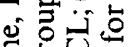

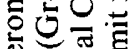

=

$\mathscr{S}_{\infty}^{\infty}$

늘

$\sum{ }^{\infty} m \sigma_{0}^{\infty} \frac{0}{0}$

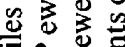

능문

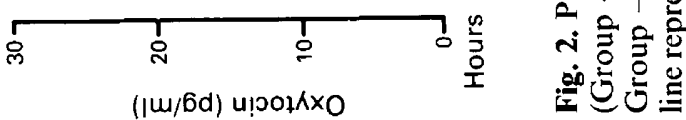




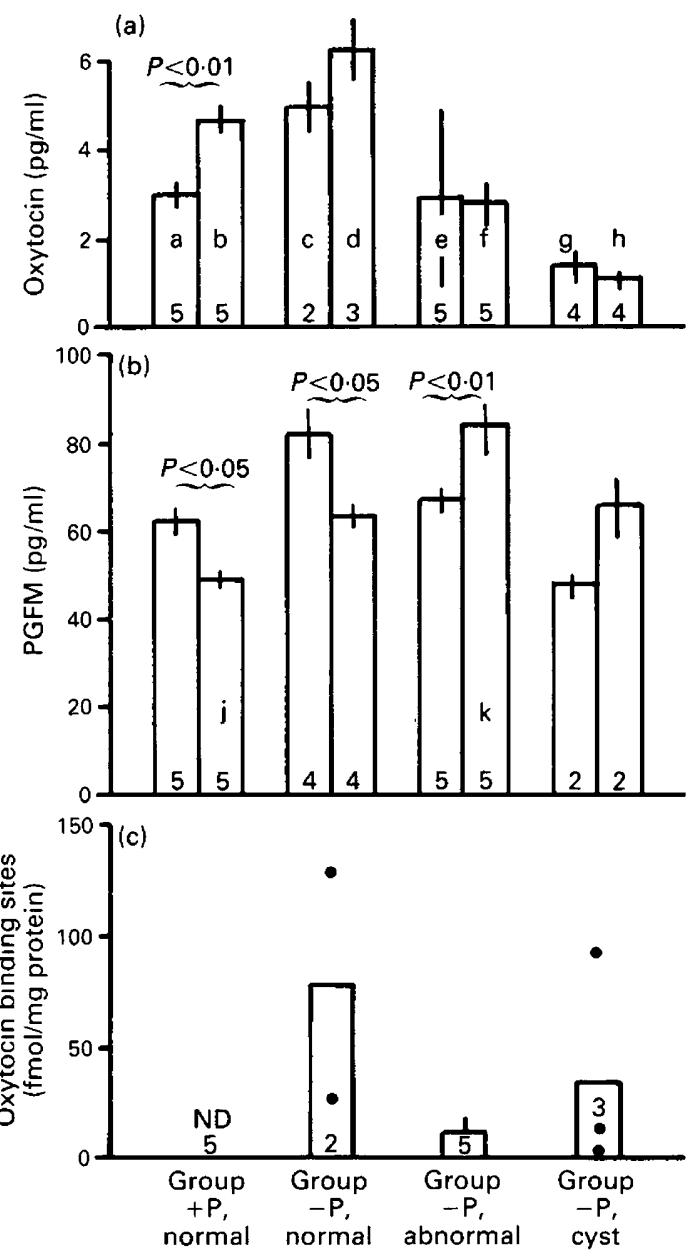

Fig. 3. Mean ( \pm s.e.m.) concentrations of (a) oxytocin, (b) PGFM, and (c) endometrial oxytocin binding sites on Day 5 in anoestrous ewes treated with $\mathrm{GnRH}(250 \mathrm{ng} / 2 \mathrm{~h}$ ) for $36 \mathrm{~h}$ (Group $+\mathrm{P}$ ewes) or $18 \mathrm{~h}$ (Group $-\mathrm{P}$ ewes) plus a bolus injection of GnRH $(125 \mu \mathrm{g})$. Blood samples were collected every $30 \mathrm{~min}$ for $8 \mathrm{~h}$ on Days 3 and 5 . The ewes have been divided into 4 groups on the basis of their response to treatment: Group +P ewes with normal CL, Group - P ewes with normal $C L$, Group -P ewes with CL plus luteinized cysts, and Group - P ewes with luteinized cysts only. The no. of animals sampled per group is shown. ND = not detectable. Significant differences (ANOVA) between days within groups are marked. Significant differences within days between groups were as follows: c $>$ a, $P<0.05$; d $>$ b, $P<0.05$; $\mathrm{f}<\mathrm{b}, P<0.05 ; \mathrm{f}<\mathrm{d}, P<0.01 ; \mathrm{g}<\mathrm{a}$, c or e, $P$ at least $<0.05 ; \mathrm{h}<\mathrm{b}, \mathrm{d}, \mathrm{f}, P$ at least $<0.05$; $\mathrm{k}>\mathrm{j}, P<0.05$.

of GnRH. All of the Group - P Day-5 ewes with CL only exhibited 'normal' luteal function, whereas all of the Group - P Day-5 ewes with $C L+$ cysts exhibited 'abnormal' function. The results of the Group - P Day-3 ewes were consistent with this, although it was too soon to see whether a progesterone fall occurred in the one Day-3 ewe which had both a CL and a cyst. The ewes with cysts only showed a variety of response, with progesterone values either increasing and then decreasing $(\mathrm{N}=2)$, remaining low until Day $3(\mathrm{~N}=2)$ or showing a sustained increase between Days 3 and $5(\mathrm{~N}=3)$. 


\section{Oxytocin and PGFM profiles}

All of the ewes killed on Day 5 were sampled every $30 \mathrm{~min}$ for two 8-h periods on Days 3 and 5 respectively for measurement of oxytocin and PGFM. Typical examples of individual profiles are illustrated in Fig. 2 and the mean values for each time period are shown in Fig. 3. The Group $+P$ ewes showed a significant $(P<0.01)$ increase in mean oxytocin concentrations between Days 3 and 5 with the PGFM levels decreasing significantly $(P<0 \cdot 05)$ over this period. Endometrial oxytocin binding sites were undetectable $(<5 \mathrm{fmol} / \mathrm{mg}$ protein) in all 5 animals. Although the Group $-P$ 'normal' ewes were indistinguishable from this group in terms of their progesterone profiles, their plasma oxytocin concentrations were significantly $(P<0.05)$ higher during both sampling periods. Oxytocin binding site measurements were only available for 2 animals, with binding sites present in both of these. Despite this there was no obvious correlation between the release of oxytocin and PGFM. The Group - P 'abnormal' ewes with CL and cysts had variable levels of oxytocin, particularly on Day 3, but Day 5 concentrations were significantly lower than those in 'normal' ewes of Groups $-\mathrm{P}$ and $+\mathrm{P}(P<0.01$ and $P<0.05$, respectively). PGFM values increased significantly $(P<0.01)$ between Days 3 and 5 in the Group $-\mathrm{P}$ 'abnormal' ewes, whereas Group $-\mathbf{P}$ 'normal' ewes and Group $+\mathbf{P}$ 'normal' ewes both showed a significant $(P<0.05)$ decrease. The mean PGFM concentration on Day 5 in the Group $-P$ 'abnormal' ewes was significantly $(P<0.05)$ greater than that in the Group $+\mathrm{P}$ 'normal' ewes. All of the ewes in the Group $-\mathbf{P}$ 'abnormal' group had low but detectable concentrations of oxytocin binding sites at slaughter on Day 5. Within the period of sampling, 3 of these 5 ewes showed an oxytocin profile characteristic of that found during normal luteolysis, with one major surge of oxytocin within the 8-h period, associated with the release of PGFM (see Fig. 2c). In 1 ewe this occurred on Day 3, and in 2 ewes on Day 5. This coincident release pattern was not seen in any of the ewes in the other groups. The remaining 2 ewes had relatively low levels of both hormones on both days.

The 4 ewes with cysts all had significantly $(P<0.05$ at least) lower oxytocin concentrations on both days than did those in any of the other groups, although 3 of them had 'normal' progesterone profiles. PGFM levels were only measured in 2 animals and showed no particular trend. Oxytocin binding sites were again present.

\section{Follicular oestradiol concentrations}

Follicular fluid was collected from the 3 largest follicles in each ovary, but in the majority of ewes in all groups the oestradiol concentration was below the limit of assay sensitivity in the 2 smaller follicles and therefore only the oestradiol concentration in the largest follicle was used for analysis. There were no significant differences among the groups, with mean \pm s.e.m. values of $22 \pm 5 \cdot 9,14 \pm 3 \cdot 2,17 \pm 10 \cdot 5$ and $24 \pm 7 \cdot 3 \mathrm{ng}$ oestradiol $/ \mathrm{ml}$ follicular fluid in Group + P 'normal' ewes, Group - P 'normal' ewes, Group $-\mathbf{P}$ ewes with abnormal $\mathrm{CL}$ and cysts and Group $-\mathbf{P}$ ewes with cysts only, respectively.

\section{Discussion}

The present study has confirmed previous reports that progesterone priming of anoestrous ewes followed by multiple low dose $\mathrm{GnRH}$ injections and a final bolus of $\mathrm{GnRH}$ results in ovulation and apparently normal luteal function (McLeod et al., 1982; Southee et al., 1988a). In comparison, only $52 \%$ of the non-primed (Group - P) ewes treated with GnRH ovulated, and a large proportion of the resulting corpora lutea were abnormal, with ewes having short luteal phases similar to those reported by Southee et al. (1988a). In this study, but not in previous work (Hunter et al., 1988; Southee $e t$ al., 1988a), the abnormal CL were associated with luteinized cysts. In the present study a significant number of cysts had a normal external appearance and size and could be distinguished from CL only by careful histological analysis. It seems likely that in the 'abnormal' ewes some 
of the stimulated follicles develop into cysts and some into abnormal CL. The lower ovulation rate in this group, which again had not been observed in previous studies, is consistent with this interpretation.

The corpora lutea which were recovered from the Group $+\mathbf{P}$ and Group $-\mathbf{P}$ ewes on Day 3 were all of a similar weight, and plasma progesterone concentrations had started to rise. However, by Day 5 it became apparent that the Group $-P$ ewes which had ovulated could be divided into two categories based on their plasma progesterone profiles (Southee et al., 1988a). Corpora lutea which were recovered from the Group - P ewes judged to be having normal luteal phases on the basis of their plasma progesterone measurements were not different from those recovered from the Group $+\mathbf{P}$ ewes, but the $C L$ recovered from the Group $-\mathbf{P}$ 'abnormal' ewes were of significantly lower weight, had lower progesterone content and had a disorganized morphological appearance.

Concentrations of the two major hormones (oxytocin and PGF- $2 \alpha$ metabolite) known to be involved in luteolysis in sheep were measured during the growth and regression of the abnormal CL, and compared with those in ewes having normal luteal phases. In 'normal' ewes of Groups $+\mathbf{P}$ and $-P$ there was a decline in the PGFM values between Days 3 and 5, but there was a significant increase in secretion in the Group - $\mathbf{P}$ 'abnormal' ewes, and the mean level on Day 5 was significantly higher than in 'normal' ewes of Group $+\mathbf{P}$. In 3 of the 5 Group $-\mathbf{P}$ 'abnormal' ewes the frequent sampling revealed a clear association between a major peak of oxytocin and a rise in PGFM, similar to that found during normal luteolysis (Flint \& Sheldrick, 1983; Hooper et al., 1986). It is possible that in the remaining 2 ewes a similar pattern could have occurred outside the sampling period. As oxy tocin binding sites are also present it is therefore likely that regression of the abnormal corpora lutea occurs in the normal way. The fact that in these animals PGF-2 $\alpha$ was being released in a luteolytic manner after only $2-3$ days of slightly elevated progesterone secretion is in contrast with the proposal that 7-10 days of progesterone priming are required for the optimum PGF- $2 \alpha$ response of the uterus to oxytocin (Baird et al., 1976; McCracken, 1980). The concentrations of PGFM measured were similar to those reported by Flint \& Sheldrick (1983) during normal luteolysis but appeared lower than those found by Louis et al. (1977). The oxytocin binding sites were present in amounts comparable to those found in normal cyclic sheep in the early luteal phase but concentrations were lower than those reported by Sheldrick \& Flint (1985) during luteolysis. Nevertheless, they were clearly sufficient to enable oxytocin to stimulate the release of PGF- $2 \alpha$.

Oestradiol is known to have a luteolytic action in sheep (Hawk \& Bolt, 1970; Cook et al., 1974) probably by inducing the formation of oxytocin receptors (Roberts et al., 1976; Sheldrick \& Flint, 1985; Hixon \& Flint, 1987). In the present experiment follicular fluid oestradiol concentrations were not significantly different between any of the groups and so this factor cannot account for the absence of oxytocin binding sites in all the Group $+P$ 'normal' ewes in contrast to their presence in most of the Group - $\mathbf{P}$ ewes, both 'normal' and 'abnormal'. However, it may be that oestradiol concentrations had differed earlier in the luteal phase.

Whilst the 'normal' corpora lutea from the Group $+\mathrm{P}$ and $-\mathrm{P}$ ewes were indistinguishable in terms of progesterone secretion, luteal size and morphology, plasma oxytocin values were significantly higher in the Group - $\mathrm{P}$ animals on both Days 3 and 5 . Unfortunately, an extraction problem prevented the measurement of all the samples in the Group $-\mathbf{P}$, but the data available do suggest a difference in the control of oxytocin production or secretion between the Group $+\mathbf{P}$ and Group $-\mathrm{P}$ ewes which merits further investigation. Althougn previous studies have demonstrated that progesterone pretreatment has a direct effect on follicular development (Hunter et al., 1986), the present results also show that progesterone pretreatment directly or indirectly alters oxytocin secretion and endometrial receptor populations and suggest actions at the level of the uterus as well as the ovary. In addition, 3 of the 4 animals with luteinized cysts only produced 'normal' progesterone profiles, while none of them secreted significant quantities of oxytocin. These data support in-vitro evidence in ewes that the factors regulating the production of oxytocin and progesterone in luteinized granulosa cells are different (Hirst et al., 1986). A 'normal' plasma progesterone profile is often taken to indicate that ovulation and luteal development are themselves 
normal. However, this study shows that this may be misleading, as such a profile can be obtained from unruptured luteinized cysts, as previously described for the sow by Ainsworth et al. (1979) and also suggests that peptide secretion may not follow the usual pattern even when functional corpora lutea are present.

We thank Mrs A. Bufton and Miss S. A. McGoff for skilled technical assistance; Dr P. A. Denning-Kendall for help with the histology; Miss E. K. Wheatley for typing the manuscript; the AFRC, MRC, Meat and Livestock Commission and Arthur Hosier Trust for financial support; and Hoechst Pharmaceuticals for supplies of GnRH.

\section{References}

Ainsworth, L., Tsang, B.K., Downey, B.R., Baker, R.D., Marcus, G.J. \& Armstrong, D.T. (1979) Effect of indomethacin on ovulation and luteal function in gilts. Biol. Reprod. 21, 401-411.

Baird, D.T., Land, R.B., Scaramuzzi, R.J. \& Wheeler, A.G. (1976) Endocrine changes associated with luteal regression in the ewe, the secretion of ovarian oestradiol, progesterone and androstenedione and uterine prostaglandin $\mathrm{F}_{2 \alpha}$ throughout the oestrous cycle. $J$. Endocr. 69, 275-286.

Barcikowski, B., Carlson, J.C., Wilson, L. \& McCracken, J.A. (1974) The effect of exogenous estradiol-17ß on the release of prostaglandin $F_{2 u}$ from the ovine uterus. Endocrinology 95, 1340-1349.

Cook, B., Karsh, F.J., Foster, D.L. \& Nalbandov, A.V. (1974) Estrogen-induced luteolysis in the ewe: possible sites of action. Endocrinology 94, 1197-1201.

Cran, D.G. (1983) Follicular development in the sheep after priming with PMSG. J. Reprod. Fert. 67, 415423.

Flint, A.P.F. \& Sheldrick, E.L. (1983) Evidence for a systemic role for oxytocin in luteal regression in sheep. $J$. Reprod. Fert. 67, 215-225.

Foster, J.P. \& Crighton, D.B. (1974) Luteinizing hormone $(\mathrm{LH})$ release after single injections of synthetic LH-releasing hormone (LH-RH) in the ewe at three different reproductive stages and comparison with natural LH release at oestrus. Theriogenology 2, 87 100.

Foxcroft, G.R., Elsaesser, F., Stickney, K., Haynes, N.B. \& Back, H.L. (1984) Ovarian oestrogen-dependent maturation of the $\mathrm{LH} / \mathrm{FSH}$ surge mechanism during prepubertal development in the gilt. $J$. Endocr. 101, 371-380

Hawk, H.W. \& Bolt, D.J. (1970) Luteolytic effect of estradiol $17 \beta$ when administered after mid-cycle in the ewe. Biol. Reprod. 2, 275-278.

Hirst, J.J., Rice, G.E., Jenkin, G. \& Thorburn, G.D. (1986) Secretion of oxytocin and progesterone by ovine corpora lutea in vitro. Biol. Reprod. 35, 11061114.

Hixon, J.E. \& Flint, A.P.F. (1987) Effects of a luteolytic dose of oestradiol benzoate on uterine oxytocin receptor concentrations, phosphoinositide turnover and prostaglandin F-2 $\alpha$ secretion in sheep. $J$. Reprod. Fert. 79, 457-467.

Homeida, A.M. \& Cooke, R.G. (1984) Loss of biological and immunological activity of oxytocin from goat plasma on storage. J. Endocr. 101,(Suppl.), Abstr. 187.
Hooper, S.B., Watkins, W.B. \& Thorburn, G.D. (1986) Oxytocin, oxytocin-associated neurophysin and prostaglandin $F_{2 a}$ concentrations in the utero-ovarian vein of pregnant and non-pregnant sheep. Endocrinology 119, 2590-2597.

Hunter, M.G., Southee, J.A., McLeod, B.J. \& Haresign, W. (1986) Progesterone pretreatment has a direct effect on GnRH induced preovulatory follicles to determine their ability to develop into normal corpora lutea in anoestrous ewes. J. Reprod. Fert. 76, 349-363.

Hunter, M.G., Southee, J.A. \& Lamming, G.E. (1988) Function of abnormal corpora lutea in vitro after GnRH-induced ovulation in the anoestrous ewe. $J$. Reprod. Fert. 84, 139-148.

Kaker, M.L., Murray, R.D. \& Dobson, H. (1984) Plasma hormone changes in cows during induced or spontaneous calving and the early post partum period. Vet. Rec. 115, 378-382.

Louis, T.M., Parry, D.M., Robinson, J.M., Thorburn, G.D. \& Challis, J.R.G. (1977) Effects of exogenous progesterone and oestradiol on prostaglandin $F$ and 13,14, dihydro-15-oxo-prostaglandin $F_{2 a}$ concentrations in uteri and plasma of ovariectomized ewes. J. Endocr. 73, 427-439.

Lowry, O.H., Rosebrough, N.J., Farr, A.L. \& Randall, R.J. (1951) Protein measurement with the folin phenol reagent. J. biol. Chem. 193, 265-275.

McCracken, J.A. (1980) Hormone receptor control of prostaglandin $\mathrm{F}_{20}$ secretion by the ovine uterus. $A d v$. Prost. Thromb. Res. 8, 1329-1344.

McCracken, J.A., Carlson, J.C., Glew, M.C., Goding, J.R., Baird, D.T., Green, K. \& Samuelsson, B. (1972) Prostaglandin $\mathrm{F}_{2 \alpha}$ identified as a luteolytic hormone in the sheep. Nature, Lond. 238, 129-134.

McLeod, B.J., Haresign, W. \& Lamming, G.E. (1982) Response of seasonally anoestrous ewes to small-dose multiple injections of GnRH with and without progesterone pretreatment. J. Reprod. Fert. 65, 223-230.

Roberts, J.S., McCracken, J.A., Gavagan, J.E. \& Soloff, M.S. (1976) Oxytocin-stimulated release of prostaglandin $F_{2 a}$ from ovine endometrium in vitro: correlation with estrous cycle and oxytocin-receptor binding. Endocrinology 99, 1107-1114.

Sheldrick, E.L. \& Flint, A.P.F. (1985) Endocrine control of uterine oxytocin receptors in the ewe. J. Endocr. 106, 249-258.

Southee, J.A., Hunter, M.G. \& Haresign, W. (1988a) Function of abnormal corpora lutea in vivo after 
GnRH-induced ovulation in the anoestrous ewe. $J$. Reprod. Fert. 84, 131-137.

Southee, J.A., Hunter, M.G., Law, A.S. \& Haresign, W. (1988b) Effect of hysterectomy on the short lifecycle corpus luteum produced after GnRH-induced ovulation in the anoestrous ewe. J. Reprod. Fert. 84, 149 155.

Wathes, D.C. \& Swann, R.W. (1982) Is oxytocin an ovarian hormone? Nature, Lond. 297, 225-227.
Wathes, D.C., Swann, R.W., Birkett, S.D., Porter, D.G. \& Pickering, B.T. (1983) Characterization of oxytocin, vasopressin and neurophysin from the bovine corpus luteum. Endocrinology 113, 693-698.

Wathes, D.C., Guldenaar, S.E.F., Swann, R.W., Webb, R., Porter, D.G. \& Pickering, B.T. (1986) A combined radioimmunoassay and immunocytochemical study of ovarian oxytocin production during the periovulatory period in the ewe. J. Reprod. Fert. 78, 167-183.

Received 30 June 1988 